\title{
Barriers in Implementing the Dying Patient Law: The Israeli Experience - A Qualitative Study
}

\author{
Avi Zigdon ( $\square$ aviz@ariel.ac.il ) \\ Ariel University https://orcid.org/0000-0003-1849-7206 \\ Rachel Nissanholtz-Gannot \\ Ariel University
}

\section{Research}

Keywords: End-of-life, Palliative care, Physician, Law

Posted Date: July 16th, 2020

DOI: https://doi.org/10.21203/rs.3.rs-41253/v1

License: (9) This work is licensed under a Creative Commons Attribution 4.0 International License. Read Full License 


\section{Abstract}

Background Coping with end-of-life issues is a major challenge for governments and health systems. Despite progress in legislation, many barriers exist to its full implementation. This study is aimed at identifying these end-of-life barriers in relation to Israel.

Methods Qualitative in-depth interviews using professionals and decision makers in the health-care and related systems $(n=37)$ were carried out, along with two focus groups based on brainstorming techniques consisting of nurses $(n=10)$ and social workers $(n=10)$. Data was managed and analyzed using Naralyzer software.

Results Qualitative analysis showed identification of six primary barriers: 1) law, procedures, and forms; 2) clinical aspects; 3) human aspects; 4) knowledge and skills of medical teams; 5) communication; and 6) resource allocation. These were further divided into 44 sub area barriers.

Conclusions This study highlights the role of the family doctor in end-of-life by training physicians in decision-making workshops and increasing their knowledge in the field of palliative medicine. Effectively channeling resources, knowledge, and support for medical teams, by accounting for the structure and response of the units for home treatment will improve patient's access to information on and support for end-of-life laws, as well as reduce legislative barriers in other countries that face the same issues.

\section{Introduction}

Coping with patients at the end of their lives is a major issue for governments and health systems in the developed world. The approach whereby every person has the right to die with dignity, without forfeiting his autonomy and the right to make decisions about his life and death, is now accepted in Western countries [1, 2]. Nonetheless, many patients struggle with the fear of slow death and a situation where they will not be able to express their opinion on the question of which medical treatments they wish to receive, or not receive, at the end of their lives [3, 4]. Different countries reach a different balance between patient autonomy and other values [5]. Even at the individual level, differences of opinion may arise among family members and between family members and medical staff, and frequently these involve no information about the patient's wishes regarding end-of-life treatment [6-11]. Conversations with patients for end-of-life planning are associated with fewer aggressive interventions and with improved quality of life at the end of life [12]. In addition, they are linked to lower levels of depression, tension, and anxiety as well as higher levels of satisfaction in the patient's family after death $[8,12]$. In fact, the presence of written directives is correlated with less tension among family members after the patient dies [13]. On the other hand, there is also evidence that writing advance healthcare directives is not sufficient to ensure end-of-life treatment that complies with the patient's wishes [14]. In recent years, many countries have passed laws that stipulate both rules for end-of-life treatment as well as the status of the patient's pre-stipulated wishes in a situation of incompetence at the end of life $[15,16]$ (Table 1 presents the comparison of countries regarding the legality of euthanasia and assisted suicide). 
Table 1

Comparison by country of legality of euthanasia and assisted suicide

\begin{tabular}{|c|c|c|c|c|c|c|c|}
\hline Country & Euthanasia & $\begin{array}{l}\text { Assisted } \\
\text { suicide }\end{array}$ & $\begin{array}{l}\text { Passive } \\
\text { euthanasia }\end{array}$ & $\begin{array}{l}\text { Advance } \\
\text { directives }\end{array}$ & $\begin{array}{l}\text { Age } \\
\text { requirement }\end{array}$ & $\begin{array}{l}\text { Diagnosis/medical } \\
\text { condition }\end{array}$ & $\begin{array}{l}\text { Waiting } \\
\text { period }\end{array}$ \\
\hline $\begin{array}{l}\text { Netherlands } \\
{[17-22]}\end{array}$ & Permitted & Permitted & & $\begin{array}{l}\text { Recognized } \\
\text { by law }\end{array}$ & 12 & None & None \\
\hline $\begin{array}{l}\text { Belgium } \\
{[19,21,23]}\end{array}$ & Permitted & & & & None & $\begin{array}{l}\text { None - Adults } \\
\text { Children- } \\
\text { Terminally ill }\end{array}$ & \\
\hline $\begin{array}{l}\text { Luxemburg } \\
{[24,25]}\end{array}$ & Permitted & Permitted & & & 18 & None & None \\
\hline $\begin{array}{l}\text { Switzerland } \\
{[17,24]}\end{array}$ & Prohibited & *Permitted & & & None & None & None \\
\hline $\begin{array}{l}\text { Germany } \\
{[26,27]}\end{array}$ & Prohibited & Prohibited & Permitted & $\begin{array}{l}\text { Legally } \\
\text { binding }\end{array}$ & & & \\
\hline $\begin{array}{l}\text { France [28- } \\
30]\end{array}$ & Prohibited & Prohibited & $\begin{array}{l}\text { Right to receive } \\
\text { continuous, } \\
\text { deep sedation }\end{array}$ & $\begin{array}{l}\text { Legally } \\
\text { binding } \\
\text { under new } \\
\text { law of deep } \\
\text { sedation }\end{array}$ & & & \\
\hline UK [29] & Prohibited & Prohibited & Permitted & $\begin{array}{l}\text { Legally } \\
\text { binding }\end{array}$ & & & \\
\hline US [31, 33] & Prohibited & & & & & & \\
\hline $\begin{array}{l}\text { Oregon [31, } \\
34]\end{array}$ & & Permitted & & & 18 & $\begin{array}{l}\text { Terminally ill - } \\
\text { 6-month life } \\
\text { expectancy }\end{array}$ & $\begin{array}{l}15 \text { days } \\
\text { after } \\
\text { verbal } \\
\text { request, } \\
48 \text { hours } \\
\text { after } \\
\text { written } \\
\text { request }\end{array}$ \\
\hline $\begin{array}{l}\text { Washington } \\
\text { [35] }\end{array}$ & & Permitted & & & 18 & $\begin{array}{l}\text { Terminally ill - } \\
\text { 6-month life } \\
\text { expectancy }\end{array}$ & $\begin{array}{l}15 \text { days } \\
\text { after } \\
\text { verbal } \\
\text { request, } \\
48 \text { hours } \\
\text { after } \\
\text { written } \\
\text { request }\end{array}$ \\
\hline $\begin{array}{l}\text { Vermont } \\
{[35]}\end{array}$ & & Permitted & & & 18 & $\begin{array}{l}\text { Terminally ill - } \\
\text { 6-month life } \\
\text { expectancy }\end{array}$ & $\begin{array}{l}15 \text { days } \\
\text { after } \\
\text { verbal } \\
\text { request, } \\
48 \text { hours } \\
\text { after } \\
\text { written } \\
\text { request }\end{array}$ \\
\hline Canada [36] & Permitted & $\begin{array}{l}\text { Permitted } \\
\text { except in } \\
\text { Quebec }\end{array}$ & & & 18 & None & $\begin{array}{l}10 \text { days } \\
\text { after } \\
\text { written } \\
\text { request }\end{array}$ \\
\hline $\begin{array}{l}\text { Colombia } \\
\text { [36] }\end{array}$ & $\begin{array}{l}\text { Permitted (to } \\
\text { some extent) } \\
\text { since } 1977\end{array}$ & & & & 18 & Terminally ill & $\begin{array}{l}15 \text { days } \\
\text { after } \\
\text { committee } \\
\text { approval }\end{array}$ \\
\hline $\begin{array}{l}\text { India [37- } \\
40]\end{array}$ & Prohibited & Prohibited & $\begin{array}{l}\text { Preconditions } \\
\text { were defined }\end{array}$ & & & & \\
\hline
\end{tabular}




\begin{tabular}{|c|c|c|c|c|c|c|c|}
\hline Country & Euthanasia & $\begin{array}{l}\text { Assisted } \\
\text { suicide }\end{array}$ & $\begin{array}{l}\text { Passive } \\
\text { euthanasia }\end{array}$ & $\begin{array}{l}\text { Advance } \\
\text { directives }\end{array}$ & $\begin{array}{l}\text { Age } \\
\text { requirement }\end{array}$ & $\begin{array}{l}\text { Diagnosis/medical } \\
\text { condition }\end{array}$ & $\begin{array}{l}\text { Waiting } \\
\text { period }\end{array}$ \\
\hline $\begin{array}{l}\text { Victoria- } \\
\text { Australia } \\
\text { [41] }\end{array}$ & & $\begin{array}{l}\text { Voluntary } \\
\text { assisted } \\
\text { dying }\end{array}$ & & & & & \\
\hline $\begin{array}{l}\text { Japan }[23, \\
42]\end{array}$ & $\begin{array}{l}\text { Prohibited but } \\
\text { was discussed in } \\
\text { the past and } \\
\text { preliminary } \\
\text { conditions set }\end{array}$ & Prohibited & $\begin{array}{l}\text { Prohibited but } \\
\text { was discussed } \\
\text { in the past and } \\
\text { preconditions } \\
\text { set }\end{array}$ & & & & \\
\hline Israel [43] & Prohibited & Prohibited & $\begin{array}{l}\text { Permitted under } \\
\text { certain } \\
\text { conditions } \\
\text { defined by law }\end{array}$ & $\begin{array}{l}\text { Recognized } \\
\text { by law }\end{array}$ & 17 & $\begin{array}{l}\text { Stipulated in } \\
\text { advance } \\
\text { healthcare } \\
\text { directives }\end{array}$ & None \\
\hline
\end{tabular}

Table 1: Comparison by country of the legality of euthanasia and assisted suicide

\section{[Insert here Table 1: Comparison by country of the legality of euthanasia and assisted suicide]}

* Article 115 of the penal code considers assistance to suicide a crime only if the motive was selfish.

However, many doctors are concerned that medical actions put them at risk of prosecution when their actions may precipitate death [44], and thus they wait for the patient to raise the issue $[45,46]$. The difficulties of communication among family members, and not only with the medical establishment [47], do not always allow for decision-making that is based on the patient's personal free will [48, 49]. Hence, there is a need to teach and educate medical teams to talk with their patients about end of life issues and help them fulfill instructions regarding their wishes [50]. Models have even been developed for integrating social workers into the patient's end-of-life decision-making process [51].

In 2005, The Dying Patient Law was enacted in Israel, which is an example of how the State of Israel deals with these issues. However, despite its enactment a decade ago, its implementation has proven faulty. The law is based on the values of the State of Israel as a democratic state and takes into account a variety of religious and moral concepts (Sect. 1 (b) of the law) [43]. In formulating this legislation, various ethical values were taken into account, including: the principle of the sanctity of life, the quality of life principle, the principle of prevention of pain and suffering, and the principle of autonomy.

Along with the desire to allow the patient to make end-of-life decisions, there are quite a few barriers to the implementation of laws dealing with the end of life. These include lack of time to discuss the subject, a difficult and cumbersome medical form containing advance healthcare directives, and the basic responsibility of doctors to act to save and prolong life [52]. What also emerges from the doctors' point of view is that they do not agree with legislation that would permit physician-assisted suicide [53]. From the patient's perspective, it was found that educated, less religious elderly people are more interested than others in being involved in decision-making at the end of their lives [54]. Furthermore, patient-focus groups raised concerns about the doctors' role in disconnecting patients from medical devices and expressed empathy with physicians who might have moral reservations [55]. Open communication and reflective listening are essential in examining the barriers in the various issues. From studies it emerges that a new approach is needed to supplement the traditional research tools in terms of laws that regulate the end of life of a dying patient [56].

\section{Objective}

The aims of the study are to identify and map the barriers to the implementation of legislation relating to the dying patient in Israel from the viewpoint of healthcare teams and leaders in the Israeli health system in order to propose solutions for reducing legislative barriers as well as share the Israeli experience with other countries who face these issues. Despite progress in dealing with the issue and the very existence of legislation in Israel and in other Western countries, many barriers exist to implementing such legislation in the Western world, and not only in Israel.

\section{Methods}

\section{Study design and Data collection}


The study is comprised of two major sections. Part 1 includes 37 in-depth interviews with professionals and decision makers on the Dying Patient Law in the health system and Part 2 includes two focus-groups comprised of nurses and social workers. Each section is based on a different research tool. In both parts, the interviewees were codified using letter "N" (Nurse), "M" (Manager), "FGSW" (Focus group social workers), "P" (Physician), "SW" (Social-worker), "H" (Hospice) and "PA" (Patient Advocacy) followed by an ordinary number.

\section{Part 1 - In-depth interviews with professionals and decision makers}

We conducted in-depth interviews with 37 professionals and decision makers who are engaged with the issue of the dying patient in the health care system. (Table 2 presents the Characteristics of Sample In-depth interviews). The interviews were conducted face to face and lasted between 45 and 75 minutes.

Table 2

Characteristics of Sample - In-depth interviews

\begin{tabular}{|c|c|c|c|}
\hline & Male & Female & Total \\
\hline Health fund representatives & & & 14 \\
\hline Family doctors & 3 & & \\
\hline Doctors in homecare units & 2 & & \\
\hline Nurses in homecare units & 1 & 1 & \\
\hline Doctor in home hospice unit & & 1 & \\
\hline Staff workers & 2 & 4 & \\
\hline Representatives of general hospitals & & & 11 \\
\hline Doctors at administrative level & 4 & 1 & \\
\hline Social workers & & 3 & \\
\hline Nurses & & 2 & \\
\hline Ethics advisors & & 1 & \\
\hline Representatives of old age homes and assisted living & & & 6 \\
\hline Administrative positions & 3 & 1 & \\
\hline Nurses & & 1 & \\
\hline Social worker & & 1 & \\
\hline Health Ministry representatives & & & 2 \\
\hline Staff workers involved in design, implementation, and supervision of the law & 2 & & \\
\hline Hospice representatives & & & 2 \\
\hline Owner of company supplying home hospice services (physician) & 1 & & \\
\hline Director of institutional hospice (physician) & & 1 & \\
\hline NGOs and private organizations & & & 2 \\
\hline Jurist & & 1 & \\
\hline Social worker & 1 & & \\
\hline TOTAL & 19 & 18 & 37 \\
\hline
\end{tabular}

The interviewees were selected using the "snowball" method, in order to reach a diverse sample of interviewees from various levels (field personnel, managers of treatment units, and policy makers in staff positions), professions (doctors, nurses, social workers, and experts in law and ethics), and institutions (health-funds, hospitals, hospices and nursing homes, representatives of related associations, and Ministry of Health representatives). At the beginning of each interview, we asked the interviewees' consent to record the interview. The taped interviews were transcribed, with two exceptions where the interviewees refused to be recorded. The interviews were conducted by means of an interview manual, which uses guiding questions, but enables a conversation that can develop in different directions. This method allows 
the researcher to remain attentive to the research subject and the unique issues raised, on the one hand, while not forgetting to ask about substantive issues related to the research topic [57]. The interview manual places a different emphasis on each interview, depending on the issues relevant to the interviewee's position and the institution to which the interviewee belongs.

All the interviewees were asked about issues relating to the Dying Patient Law: How the law affected their work; actions taken at the institution where they work in order to implement the law; degree of awareness of the law and the subject of end-of-life treatment in general; objections they encounter regarding the law and dealing with end-of-life treatment in general; their perception of the extent to which the law is applied; possible reasons for non-implementation or incomplete implementation of the law; their perception of the importance and necessity of the law; changes that have taken place in end-of-life treatment in recent years (not necessarily as a result of the law); and ways to improve the response to patients at the end of their lives, in terms of the quality of the treatment and exercising their right to decide on how they will be treated.

\section{Part Two - Focus Groups}

We held two focus groups, one of nurses and the other of social-workers. The representatives were sent by the authorities in the health funds or in the nursing homes. Each of the focus groups had 10 participants. The group of nurses included 10 female nurses and the social workers group included 8 women and 2 men, from the health funds and from institutions for seniors. (Table 3 presents the Characteristics of Sample: Focus Groups)

Table 3

Characteristics of Sample - Focus Groups

\begin{tabular}{|c|c|c|c|}
\hline & Focus group Nurses & Focus group Social workers & Total \\
\hline Clalit Health Fund & 3 & 1 & 4 \\
\hline Nurses & 3 & & \\
\hline Social workers & & 1 & \\
\hline Maccabi Health Fund & 2 & 3 & 5 \\
\hline Nurses & 2 & & \\
\hline Social workers & & 3 & \\
\hline Meuchedet Health Fund & 2 & 3 & 5 \\
\hline Nurses & 2 & & \\
\hline Social workers & & 3 & \\
\hline Leumit Health Fund & 1 & 1 & 2 \\
\hline Nurses & 1 & & \\
\hline Social workers & & 1 & \\
\hline Facilities for senior citizens & 2 & 2 & 4 \\
\hline Nurses & 2 & & \\
\hline Social workers & & 2 & \\
\hline TOTAL & 10 & 10 & 20 \\
\hline
\end{tabular}

The focus groups were conducted using brainstorming techniques [58]. The questions were open-ended, and the researchers made sure that they received feedback from each of the participants. The discussions in the focus groups were recorded and summarized by one of the researchers. Each focus group was presented with six main questions during the instruction phase: 1) How do you define successful treatment of a patient at the end of life; 2) What difficulties do you experience during a patient's end-of-life treatment; 3) What is your organization's attitude to the subject of holding conversations with the patient to clarify preferences at the end of life; 4) How would you like to see the treatment of patients at the end of their lives conducted by your organization; 5) What would help you or the system achieve the situation you described; and 6) Have you witnessed any change over the past few years in end-of-life treatment?

\section{Qualitative data analysis}


In order to identify all the barriers to implementing the law, the study findings were analyzed using Naralyzer, the qualitative analysis software, which enables content analysis by building category trees that bring together all the contents relating to a particular category but distinguish between the different groups of interviewees. This method enabled us to identify the barriers to end-of-life legislation, those that emerged from the in-depth interviews, and those that emerged from the focus groups.

\section{Results}

This study found that there are still many barriers to the implementation of the law, which are expressed in six main themes: The law, procedures, and forms; Human aspects of the patient, the family, and the medical staff; Knowledge and skills of the medical teams; System resources; Clinical aspects; and Communication between clinicians and medical organizations. In these six themes, we identified 44 areas that generate these barriers as reflected in the Results section. (See Fig. 1)

[Insert here Fig. 1 - Barriers in the implementation of the Dying Patient Law]

Barriers stemming from the law, procedures, and forms

The form which the patient is asked to sign constitutes one of the main obstacles to the implementation of the Dying Patient Law in the State of Israel. The form is written in legal language and is not comprehensible to the average person; it is too long and full of details, which promotes mistakes in filling it out, making it hard for the patient to participate in the signing process. A homecare nurse expressed frustration with the forms thus: "The ones who wrote the form are lawyers, where covering for themselves was the most important part for them, not the people [...] who fill it out with the patients." [FGN4] For clinicians, therefore, legal emphasis and failure to allow for expression of patient opinion mean that the forms fall short of achieving their goal. Even after receiving comprehensive medical explanations, the individual rarely has the necessary ability to understand the full significance of the medical treatments listed in the form. As one manager noted: "The form has a lot of demanding and difficult questions, and even if the patient receives the best explanation from the best doctor who will explain the medical terms to him, he will have trouble answering the questions." [M7] On the one hand, according to the social workers, the fact that clarifying the patient's preferences and following the directives are not a regular part of the protocol of a home visit impedes the implementation of the law: "We have to make a very clear protocol routine: $A, B, C, D[\ldots]$, and you have to mark the $X$ in the right place." [FGSW7] On the other hand, there was opposition to this assertion in the nurses' focus group, with their opinion being that clinicians should be left with the flexibility to clarify these issues in a manner that is timely and appropriate for each one of them: "The most important thing is to open up a space, to let you talk about what you would like and what's important to you and what your preferences are." [FGN4].

\section{Barriers arising from clinical aspects}

The law states that a dying patient is one whose expected life expectancy is six months. We found that there is a technical difficulty in determining a prognosis of six months, especially for diseases such as dementia. Most interviewees objected to the use of the definition of a six-month prognosis because it is not perceived as clinically significant. On the face of it, when dementia patients lose their competence, it is forbidden by law to refrain from giving life-prolonging treatment, even if the patient has explicitly expressed a desire not to prolong life, close to the time of losing competence, since they are not defined as "dying patients". This prohibition causes difficulty and great resentment among many care teams. In their opinion, the law clashes with accepted professional views. In the words of one manager:

"They put the staff in an impossible situation [...] Help the patient and you're a criminal, or else force upon the patient treatment that an hour ago, a day ago, a week ago, he told you he did not want." [M3] Although there was great support for the spirit of the law and the principles it charts, there was still criticism and frustration that the details of the law do not match the clinical reality. In many cases, the end-of-life patient has many diseases, and it is not clear which of these diseases will result in the patient's death. Therefore, it is not clear which treatment is considered "adjunctive therapy". Even if there is a basic awareness of the stipulations of the law, the tendency in clinical work is to ignore these details in the treatment of a specific patient, as long as the medical staff and the patient's family agree on the treatment plan.

\section{Barriers arising from human aspects - patient, family and medical staff}

Implementing the Dying Patient Law creates personal and cultural barriers for the staff, the patient, and the family, as well as a cultural difficulty in dealing with death. Some interviewees noted that many physicians still take a paternalistic approach, and their perception of whether to refrain from treatment due to futility or to extend life is a professional decision made by the physician alone. However, it was noted that there has been progress in doctors' perceptions, and in recent years awareness has been increasing, especially among younger doctors. The older the patients and the poorer their cognitive state, the less awareness they have of their rights, with the medical staff less disposed to speak to them directly. Most of the communication in these situations is focused on the family, even if the patient is competent. As one social worker put it: "When I come in at the stage of home care, I feel a sense of having missed out because I did not know the patient before [...] I know that the hospital will determine that he is not competent." [SW3] It also emerges that the percentage of

Page $7 / 14$ 
citizens prepared for the end of life is very low, and if the patient did not do early preparatory work while he was healthy or in the nonhazardous stages of his illness, it will be much harder to start thinking about end of life in the stages when death is approaching. As one nurse noted: "I really see that patients are dodging the possibility that 'maybe I will not survive' [...] It is very threatening." [N1] In practice, people from different cultures will not necessarily agree on whether it is right to tell the patient everything about their condition, and, in cases of disagreement, the clinicians do not know how to act. The patient's family plays a very significant part in the treatment process at the end of life. Hence, when the patient is in the early stages of the disease or is still healthy, it is important to promote communication within the family on the issue. However, it is acknowledged that encouraging communication is not a feasible solution for every family, and, in any event, a way must be found to deal with cases where there is a conflict between family and patient wishes.

\section{Barriers in the knowledge and skills of the medical teams}

Some of the most significant barriers to the implementation of the law raised in the study relate to the lack of knowledge and skills among the clinical staff. Almost all of the interviewers noted that most of the staff lacked the complex proficiency needed for holding painful conversations with end-of-life patients. In addition, a cultural barrier, especially among doctors, makes it difficult to cope with the subject of death. Many noted that there is no awareness of the obligation imposed by law on the medical staff in all matters relating to informing the patient of his condition and exploring his preferences.

In fact, there is no clear statement about who should be responsible for having conversations with patients towards the end-of-life. The unclear issue of responsibility creates ambiguity, which touches not only upon the family and hospital doctors, but also the experts in the community, home care units, and nursing homes. A physician said: "The loop between the care givers is not closed, and everyone says, 'Why should I do it? Let him/her do it!' But what is right?" [P1] The difficulty of establishing rules on the subject came up in the interviews, since the right person to conduct the conversation depends very much on the specific situation, and especially on the type of illness. As one social worker noted: "The question of who will manage this issue-the community or the hospital-depends on the illness" [SW4]. Moreover, a number of palliative experts noted that there is a difficulty since the Ministry of Health has not established clear standards for palliative care, and this undermines the quality of treatment and the equality of access. Some of the participants in the study think that nursing homes and assisted living facilities are actually an ideal place for palliative care outside the hospital.

\section{Barriers in communication between care teams and medical institutions}

When a patient from the community is admitted to the hospital, the medical staff usually does not have time to clarify their preferences. Even if the patient arrives with the forms containing his instructions, the staff is not able to check if the advance directives are valid and relevant. In this case, the staff will tend towards over-treatment unless the patient has a relative who is self-confident and can insist on the patient's wishes. This situation has been noted many times in this research as a barrier to fulfilling the patient's will. Some of the interviewees noted the importance of translating the directives into specific clinical instructions for dying patients, such as the Physician Orders for Life-Sustaining Treatment (POLST) form used in the US. Others noted that the solution should be to improve end-of-life services in the community so that patients who are receiving only palliative treatment will not even be taken to a hospital in an emergency.

In nursing homes, it also emerged that an unequivocal demand made of the Health Ministry is essential in order to have the matter of the advance directives implemented. As one manager said: "In institutions we operate according to the procedures of the Ministry of Health. That is what the Ministry of Health stipulates! If they don't ask, we don't act." [M1] The interviews reveal that involving the management, especially hospital managers and department managers, is critical to the successful implementation of the law and palliative care: "From inside the hospital management, it is possible to bring about change. It is our responsibility [...] There are priorities, and this was not one of them. The director of the hospital, and not the nursing director, should have led this. '[P8]

The focus groups also clearly demonstrated the need to implement the issue from the top-down -the health ministry directorate and the health funds, through the directors of the wards to the staff members themselves - in order to move beyond local initiatives. Nevertheless, the management may prove to be a barrier: "The social workers and the nurses in the field were happy to go in this direction, but even here the administrative factors are a barrier. They are very afraid that things will not be done exactly according to the forms and the law, and then they will not be covered." [P9] When staff members talk about end-of-life options, they sometimes encounter resistance because they fail to make it clear that acknowledging the end-of-life and the cessation of aggressive therapies does not mean not abandoning the patients.

\section{Barriers in resource allocation}

The enactment of the law was not accompanied by the addition of dedicated resources to the organizations which are responsible for its implementation. Conversations to clarify preferences and instructions take a long time, especially for a patient with complex care needs. The problem is not only allocating the time, but also the emotional availability such conversations require. Physicians that we interviewed 
stated that it was impossible to hold such a conversation during the frenzied pace of a normal working day, when patients were waiting outside: "How can I even talk to them about 'what would you like?' Do I have to go to their home? Not to do it in the clinic?" [P12] The issue of compensation appears to be secondary compared to the issue of time, and if the doctors had time for it and were convinced that this was correct medicine, there would be no need for specific compensation, just as there is none for other types of treatment. In the words of one nurse: "Once a chronic disease is detected [...] it takes time, skill, a lot of listening. Unfortunately, this does not happen. It happens more with patients with severe complex care needs." [N6] Another aspect of lack of resources is lack of additional budgets earmarked for the expansion of palliative services, with an emphasis on low of standards for experts and those responsible for implementation. Moreover, insufficient funds can detrimentally affect training and mentoring of teams: "Everything that the Ministry of Health decides and is not earmarked specifically in the budget, such as the guidelines regarding palliative medicine [...] is always problematic. And then everyone improvises [...] just in order to discharge their minimal obligation." [P10] In the health funds, developing the field of palliative care requires reorganization in the homecare units so as to support the possibility of dying at home. This option requires higher availability of therapeutic responses. Although palliative care at home may be the most appropriate for end-of-life patients, the system is unprepared for this eventuality, with the costs of attendant nursing care potentially a significant barrier for the patient's family compared with hospitalization options.

\section{Discussion}

The issue of dying patients is often difficult and painful, provoking ethical, moral, ideological, and religious disputes. This study sheds light on the difficulties and many obstacles to the implementation of decisions regarding the end of life. Such difficulties even exist if cultural understanding that such laws are necessary in order to respect the wishes of the individual at the end of life. Implementing and applying the legal instructions create many challenges stemming from impediments in the broader setting where the actual implementation of the law takes place. This study shows that there has been significant progress in terms of the perception of the "dying patient," of the individual expressing his will and having it honored. The health system teams are more aware of the patient's wishes and understand the importance of upholding them. The change that has occurred in this area may be the result of, among other things, legislation that has slowly permeated society, technological progress, and knowledge that has accumulated. Even if the study participants had criticism of the details of the law, the general attitude was that the law has done important work in raising awareness of the issue and in urging medical bodies to take action. In addition, it legitimized practices that preceded the legislation and clarified legal and ethical issues. At the same time, the law made it easier for physicians to document medical guidelines for withholding treatment, which they feared to do before the law was passed.

Other research data indicated barriers that were reflected in the difficulty in discussing the subject with patients and families [52]. This study shows that the law can address this barrier, opening up the conversation possibilities on sensitive end-of-life matters. The literature further shows that physicians do not agree with legislation that permits physician-assisted suicide [53], and apprehensions were voiced about the doctors' function in disconnecting patients from life-support devices. ${ }^{45}$ Indeed, the issue of the central role of the physician was also raised in this study and in many countries around the world. However, until otherwise established, the one who determines the handling of the dying patient, as reflected in the legislation, is still the doctor. Thus, in the Netherlands [17-22], Belgium [19, 21, 23], Luxembourg [24, 25], Quebec [24, 25], and the United States [31,33], countries where physician-assisted suicide is permitted, only a physician can terminate the life of a patient and he is obligated to consult an additional physician before any action is taken. In these countries and in Switzerland $[17,24]$, prescribing a medication used to terminate life can be done only by a physician. Even in countries where active euthanasia is prohibited, the doctor has significant standing. In India [37-40], for example, disconnecting a patient from a respirator is carried out at the discretion of family members or a doctor. In England [29], the physician has the authority to refuse a patient's request that treatment be continued if he believes that the treatment is not helping the patient. This is in contrast to Israel [43], where the physician is required to continue to treat the patient who wishes it, even if there is no medical justification for doing so.

One of the obstacles mentioned is unawareness of the details of the law, which creates a gap between the rights granted by law and the implementation of these rights. This gap requires proactive measures to increase awareness of the subject of end-of-life planning. One of the ideas that was raised in the study is that directing consciousness-raising action or thinking can be achieved by educating the public, in general, and talks with family members of patients. This does not mean forcing the use of these rights, but becoming familiar with the legislation and creating an awareness among the public, emphasizing that recognizing the basic right of a person to plan the end of his life is unavoidable. The role of the medical system should be to provide all relevant medical information and inform patients that the option of the advanced directives exists. But the patient's coping with emotional consequences and uncertainties as well as the continuation of the discussion with the family will be carried out with other factors, more oriented to social and spiritual dimensions. Training physicians, and in particular recruiting senior physicians to implement the subject through workshops on decision-making, communication, and end-of-life treatment, may contribute to increasing awareness and promoting the engagement of the entire medical staff. As part of the solutions

Page 9/14 
proposed by the interviewees in this study, it was found that it is important for physicians in the units caring for dying patients to become more knowledgeable about the field of palliative medicine, so that they can provide basic palliative care without having to refer to specialists in the field.

The issue of the "products of the law" arose in most of the interviews. According to the interviewees, should be to simplify the forms and make them more user-friendly. As one specialist in patient advocacy noted, one constructive step would be "to simplify the form and turn it from the nine-page form it is today to a maximum of two to two-and-a-half pages." [PA1]

In the last few years, many participants have detected more sensitivity to the existence of patient rights and more awareness that it is not right to give treatment at all costs. However, the study participants also noted that the barriers raised are not necessarily related to the law, but rather to parallel and separate progress in the clinical approach to end-of-life quality treatment.

This issue, of course, is not restricted to Israel. Most western countries are concerned with the extent to which speeding up end of life should be permitted in societies that, in general, do not support suicide. However, in most countries, including Israel, attempted suicide is no longer considered a criminal offense. One of the reasons for the difficulty in solving the end-of-life issue is the question of whether an individual has the right to end his life. A discourse of rights implies the counterbalancing notion of obligations. Thus, recognition of a person's right to terminate his life as he wishes raises the issue of the obligation of society to assist him in doing so. Such a societal obligation runs contrary to the received views of care teams, and physicians in particular, as well as the perception that the right to life is one that cannot be relinquished. That is, a person given life cannot decide to "waive" it. The prevailing view is that the right to life is very basic to, and in the fabric of, individual rights. As such, it is important not only to the individual, but also to society.

\section{Limitations}

This study, as all others, has limitations that stem from the methods used. Qualitative in-depth interviews with interviewees that play a central role in an organization represent the organization's opinion and not that of the public. In this research patients were not sampled or interviewed, and the focus group of nurses and social workers represent only the opinion of medical staffs.

\section{Conclusions}

In Israel and the western world, the relationship between clinician-care teams and patients is strong. Medical teams in the community are in daily contact with elderly and sick populations. However, the proportionate increase in the elderly population of developed economies such as Israel in relation to the number of medical teams will, in the not-too distant future, strain care team access to this demographic. This will thus affect implementation of laws dealing with end-of-life. Therefore, it is recommended that the role of the family doctor in end-of-life treatment should be strengthened. The structure and response of the units for home treatment should be taken into account, to enable greater accessibility to homes for the aged, medical assistance housing, and hospice homes that can provide appropriate response to endof-life patient needs. At the same time, awareness must be raised among the general population, medical staff as well as other therapists in the health system. This is needed to channel the resources, knowledge, support, and tools to these medical teams for improving treatment and responding to patients who need information and support for mastering end-of-life laws, with the aim of promoting the legitimate rights of all citizens who are at the end of their lives.

\section{Declarations}

\section{Ethical approval}

Ethical approval for this study was given by the Myers-JDC-Brookdale Institute. Informed consent was not required.

\section{Consent for publication- Not applicable}

\section{Availability of data and materials}

Data sharing is not applicable to this article as no datasets were generated or analyzed during the current study.

\section{Competing interests}

The authors are not affiliated to any other company or organization that may be interested in its publication. 


\section{Funding sources}

This work was supported by The Israel National Institute for Health Policy Research (NIHP) [grant number R / 2013/82]

\section{Authors' contributions}

Avi Zigdon and Rachel Nissanholtz-Gannot contributed equally to this work. Both authors have participated in the design and in the writeup of the manuscript to take public responsibility for it.

\section{Acknowledgments}

The researchers wish to thank the Israel National Institute for Health Policy Research (NIHP), which supported the funding of this research, and Michal Gordon, for her assistance in collecting the material and conducting the preliminary analysis.

\section{References}

1. Gillick MR. Advance care planning. N Engl J Med. 2004;350(1):7-8. doi:10.1056/NEJMp038202.

2. Hampson LA, Emanuel EJ. The prognosis for changes in end-of-life care after the Schiavo case. Health Aff (Millwood). 2005;24(4):972-5. doi:https://doi.org/10.1377/hlthaff.24.4.972.

3. Lynn J, Schall MW, Milne C, Nolan KM, Kabcenell A. Quality improvements in end of life care: Insights from two collaboratives. Jt Comm J Qual Improv. 2000;26(5):254-67. doi:https://doi.org/10.1016/S1070-3241(00)26020-3.

4. Lynn J. Serving patients who may die soon and their families: The role of hospice and other services. JAMA. 2001;285(7):925-32. doi:10.1001/jama.285.7.925.

5. Onwuteaka-Philipsen BD, Fisher S, Cartwright C, et al. End-of-life decision making in Europe and Australia: A physician survey. Arch Intern Med. 2006;166(8):921-9. doi:10.1001/archinte.166.8.921.

6. Casarett DJ, Quill TE. "I'm not ready for hospice": Strategies for timely and effective hospice discussions. Ann Intern Med. 2007; 146(6):443-9. Available: http://www.lumen.luc.edu/LUMEN/MedEd/EOL/strategies\%20for\%20hospice\%20discussions.pdf. Accessed 20 Jan 2020 .

7. Connors AF, Dawson NV, Desbiens NA, et al. A controlled trial to improve care for seriously III hospitalized patients: The study to understand prognoses and preferences for outcomes and risks of treatments (SUPPORT). JAMA. 1995;274(20):1591-8. doi:10.1001/jama.1995.03530200027032.

8. Detering KM, Hancock AD, Reade MC, Silvester W. The impact of advance care planning on end of life care in elderly patients: Randomised controlled trial. BMJ. 2010;340. doi:https://doi.org/10.1136/bmj.c1345.

9. Mack JW, Weeks JC, Wright AA, Block SD, Prigerson HG. End-of-life discussions, goal attainment, and distress at the end of life: Predictors and outcomes of receipt of care consistent with preferences. J Clin Oncol. 2010;28(7):1203-8. doi:10.1200/JC0.2009.25.4672.

10. Teno JM, Licks S, Lynn J, et al. Do advance directives provide instructions that direct care? SUPPORT investigators. Study to understand prognoses and preferences for outcomes and risks of treatment. J Am Geriatr Soc. 1997;45(4):508-12. doi:https://doi.org/10.1111/j.1532-5415.1997.tb05179.x.

11. Winzelberg GS, Hanson LC, Tulsky JA. Beyond autonomy: Diversifying end-of-life decision-making approaches to serve patients and families. J Am Geriatr Soc. 2005;53(6):1046-50. doi:https://doi.org/10.1111/j.1532-5415.2005.53317.x.

12. Wright AA, Zhang B, Ray A, et al. Associations between end-of-life discussions, patient mental health, medical care near death, and caregiver bereavement adjustment. JAMA. 2008;300(14):1665-73. doi:10.1001/jama.300.14.1665.

13. Tilden VP, Tolle SW, Nelson CA, Fields J. Family decision-making to withdraw life-sustaining treatments from hospitalized patients. Nurs Res. 2001; 50(2):105 - 15. Available: https://journals.Iww.com/nursingresearchonline/Abstract/2001/03000/Family_Decision_Making_to_Withdraw_Life_Sustaining.6.aspx. Accessed 13 Feb 2020.

14. Perkins HS. Controlling death: The false promise of advance directives. Ann Intern Med. 2007;147(1):51-7. doi:10.7326/0003-4819147-1-200707030-00008.

15. Spooner R, Willingham R. Dying with dignity: Parliamentary report recommends euthanasia laws. Legaldate. 2016;28(3):16. Available: https://search.informit.com.au/documentSummary;dn=240885496651606;res=IELAPA. Accessed 15 Feb 2020. 
16. Sudore RL, Fried TR. Redefining the "planning" in advance care planning: Preparing for end-of-life decision making. Ann Intern Med. 2010;153(4):256-61. doi:10.7326/0003-4819-153-4-201008170-00008.

17. Bosshard G, Broeckaert B, Clark D, Materstvedt LJ, Gordijn B, Müller-Busch HC. A role for doctors in assisted dying? An analysis of legal regulations and medical professional positions in six European countries. J Med Ethics. 2008;34(1):28-32. doi:http://dx.doi.org/10.1136/jme.2006.018911.

18. Van den Block L, Deschepper R, Bilsen J, Bossuyt N, Van Casteren V, Deliens L. Euthanasia and other end of life decisions and care provided in final three months of life: Nationwide retrospective study in Belgium. BMJ. 2009;339:b2772. doi:https://doi.org/10.1136/bmj.b2772.

19. Deliens L, van der Wal G. The euthanasia law in Belgium and the Netherlands. Lancet. 2003;362(9391):1239-40. doi:https://doi.org/10.1016/S0140-6736(03)14520-5.

20. de Boer ME, Dröes R, Jonker C, Eefsting JA, Hertogh, Cees MPM. Advance directives for euthanasia in dementia: How do they affect resident care in Dutch nursing homes? Experiences of physicians and relatives. J Am Geriatr Soc. 2011;59(6):989-96. doi:https://doi.org/10.1111/j.1532-5415.2011.03414.x.

21. Rurup ML, Onwuteaka-Philipsen BD, van der Heide A, van der Wal G, Deeg DJH. Frequency and determinants of advance directives concerning end-of-life care in the Netherlands. Soc Sci Med. 2006;62(6):1552-63. doi:https://doi.org/10.1016/j.socscimed.2005.08.010.

22. van der Heide A, Onwuteaka-Philipsen BD, Rurup ML, et al. End-of-life practices in the Netherlands under the euthanasia act. N Engl $\mathrm{J}$ Med. 2007;356(19):1957-65. doi:10.1056/NEJMsa071143.

23. Akabayashi A. Euthanasia, assisted suicide, and cessation of life support: Japan's policy, law, and an analysis of whistle blowing in two recent mercy killing cases. Soc Sci Med. 2002;55(4):517-27. doi:https://doi.org/10.1016/S0277-9536(01)00184-8.

24. Steck N, Egger M, Maessen M, Reisch T, Zwahlen M. Euthanasia and assisted suicide in selected European countries and US states: Systematic literature review. Med Care. 2013;51(10):938-44. doi:10.1097/MLR.0b013e3182a0f427.

25. Onwuteaka-Philipsen BD, Brinkman-Stoppelenburg A, Penning C, de Jong-Krul, Gwen JF, van Delden, Johannes JM, van der Heide A. Trends in end-of-life practices before and after the enactment of the euthanasia law in the Netherlands from 1990 to 2010 : A repeated cross-sectional survey. Lancet. 2012;380(9845):908-15. doi:https://doi.org/10.1016/S0140-6736(12)61034-4.

26. Oorschot Bv, Simon A. Importance of the advance directive and the beginning of the dying process from the point of view of German doctors and judges dealing with guardianship matters: Results of an empirical survey. J Med Ethics. 2006;32(11):623-6. doi:http://dx.doi.org/10.1136/jme.2005.015032.

27. Michalsen A. Care for dying patients-German legislation. Intensive Care Med. 2007;33(10):1823-26. doi:10.1007/s00134-007-0780-2.

28. Baumann A, Audibert G, Claudot F, Puybasset L. Ethics review: End of life legislation - the French model. Crit Care. 2009;13(1):204. doi:https://doi.org/10.1186/cc7148.

29. Horn RJ. Advance directives in English and French law: Different concepts, different values, different societies. Health Care Anal. 2014;22(1):59-72. doi:https://doi.org/10.1007/s10728-012-0210-7.

30. Aubry R. End-of-life, euthanasia, and assisted suicide: An update on the situation in France. Rev Neurol. 2016;172(12):719-24. doi:https://doi.org/10.1016/j.neurol.2016.09.007.

31. Ganzini L, Nelson HD, Schmidt TA, Kraemer DF, Delorit MA, Lee MA. Physicians' experiences with the Oregon death with dignity act. N Engl J Med. 2000;342(8):557-63. doi:10.1056/NEJM200002243420806.

32. Tinetti ME. The retreat from advanced care planning. JAMA. 2012;307(9):915-6. doi:10.1001/jama.2012.229.

33. Bentur N, Emanuel LL, Cherney N. Progress in palliative care in Israel: Comparative mapping and next steps. Isr J Health Policy Res. 2012;1(1):9. doi:https://doi.org/10.1186/2045-4015-1-9.

34. Oregon Death with Dignity Act - Data summary. Oregon Health Authority. Public health division. 2016. Available: https://www.oregon.gov/oha/ph/providerpartnerresources/evaluationresearch/deathwithdignityact/documents/year19.pdf. Accessed 21 Jan 2019.

35. Emanuel EJ, Onwuteaka-Philipsen BD, Urwin JW, Cohen J. Attitudes and practices of euthanasia and physician-assisted suicide in the united states, Canada, and Europe. JAMA. 2016;316(1):79-90. doi:10.1001/jama.2016.8499.

36. Dyer O, White C, García Rada A. Assisted dying: Law and practice around the world. BMJ. 2015;351:h4481. doi:https://doi.org/10.1136/bmj.h4481.

37. Rao S. India and euthanasia: The poignant case of Aruna Shanbaug. Med Law Rev. 2011;19(4):646-56. doi:https://doi.org/10.1093/medlaw/fwr028. 
38. Myatra SN, Salins N, lyer S, et al. End-of-life care policy: An integrated care plan for the dying: A joint position statement of the Indian society of critical care medicine (ISCCM) and the Indian association of palliative care (IAPC). Indian J Crit Care Med. 2014;18(9):61535. doi:10.4103/0972-5229.140155.

39. Mishara BL, Weisstub DN. The legal status of suicide: A global review. Int J Law Psychiatry. 2016;44:54-74. doi:https://doi.org/10.1016/j.ijlp.2015.08.032.

40. Shekhawat RS, Kanchan T, Setia P, Atreya A, Krishan K. Euthanasia. Global scenario and its status in India. Sci Eng Ethics. $2017: 1-12$. doi: https://doi.org/10.1007/s11948-017-9946-7.

41. Department of Health \& Human Services. Department of Health \& Human. Ministerial advisory panel on voluntary assisted dying: Final report. 2017:1-265. Available: https://www2.health.vic.gov.au:443/about/publications/researchandreports/ministerial-advisory-panel-on-voluntary-assisted-dyingfinal-report. Accessed 22 Jan 2019.

42. Makino J, Fujitani S, Twohig B, Krasnica S, Oropello J. End-of-life considerations in the ICU in japan: Ethical and legal perspectives. J Intensive Care. 2014;2(1). doi:https://doi.org/10.1186/2052-0492-2-9.

43. Dying Patient L. 5766-2005, Israel Book of Laws, no. 2039. 15.12.2005, pp 58. Available In Hebrew: https://www.nevo.co.il/law_html/Law01/999_527.htm. Accessed 22 Jul 2019.

44. Malpas PJ, Mitchell K. “Doctors shouldn't underestimate the power that they have”: NZ doctors on the care of the dying patient. American Journal of Hospice Palliative Medicine®. 2017;34(4):301-7. doi:https://doi.org/10.1177/1049909115619906.

45. Horne G, Seymour J, Shepherd K. Advance care planning for patients with inoperable lung cancer. Int J Palliat Nurs. 2006;12(4):172-8. doi:https://doi.org/10.12968/ijpn.2006.12.4.21014.

46. Munday D, Petrova M, Dale J. Exploring preferences for place of death with terminally ill patients: Qualitative study of experiences of general practitioners and community nurses in England. BMJ. 2009;339:b2391. doi:https://doi.org/10.1136/bmj.b2391.

47. Shalev C. An old woman's power of attorney. Harefuah, 229-232 (4)148; 2009. Available: https://www.ima.org.il/medicine/ViewNewspaper.aspx?Newspaperld=14. Accessed 22 Jun 2019.

48. Singer PA, Martin DK, Kelner M. Quality end-of-life care: Patients' perspectives. JAMA. 1999;281(2):163-8. doi:10.1001/jama.281.2.163.

49. Drazen JM, Desai NR, Green P. Fighting on. N Engl J Med. 2009;360(5):444-5. doi:http://dx.doi.org/10.1056/NEJMp0809496.

50. Gott M, Gardiner C, Small N, et al. Barriers to advance care planning in chronic obstructive pulmonary disease. Palliat Med. 2009;23(7):642-8. doi:https://doi.org/10.1177/0269216309106790.

51. Wallace CL. Overcoming barriers in care for the dying: Theoretical analysis of an innovative program model. Soc Work Health Care. 2016;55(7):503-17. doi:https://doi.org/10.1080/00981389.2016.1183552.

52. Bentur N. The attitudes of physicians toward the new "dying patient act" enacted in Israel. Am J Hosp Palliat Care. 2008;25(5):361-65. doi:https://doi.org/10.1177/1049909108319266.

53. Doron D, Wexler ID, Shabtai E, Corn BW. Israeli dying patient act: Physician knowledge and attitudes. Am J Clin Oncol. 2014;37(6):597602. doi:10.1097/COC.0b013e318295b022.

54. Carmel S, Lazar A. Telling the bad news: Do the elderly want to know their diagnoses and participate in medical decision making? Harefuah. 1997;133(11):505-9. Available: https://www.ima.org.il/medicine/ViewNewspaper.aspx?Newspaperld=177. Accessed 22 Jan 2019].

55. Inthorn J, Schicktanz S, Rimon-Zarfaty N, Raz A. "What the patient wants... Lay attitudes towards end-of-life decisions in Germany and Israel. Medicine, Health Care and Philosophy.2015;18(3):329-40. doi: https://doi.org/10.1007/s11019-014-9606-5.

56. Balducci L. Death and dying: What the patient wants. Ann Oncol. 2012;23(Suppl 3):56-61. doi:https://doi.org/10.1093/annonc/mds089.

57. Patton MQ. Qualitative evaluation and research methods. United States: 1990. Available: http://catalog.hathitrust.org/Record/002165663. Accessed 15 Jun 2019.

58. Shkedi A. Words that try to touch: qualitative research - theory and practice. Tel Aviv: Ramot; 2003. Available In Hebrew: https://kotar.cet.ac.il/KotarApp/Viewer.aspx?nBookID=92549046. Accessed 11 Jun 2019.

\section{Figures}




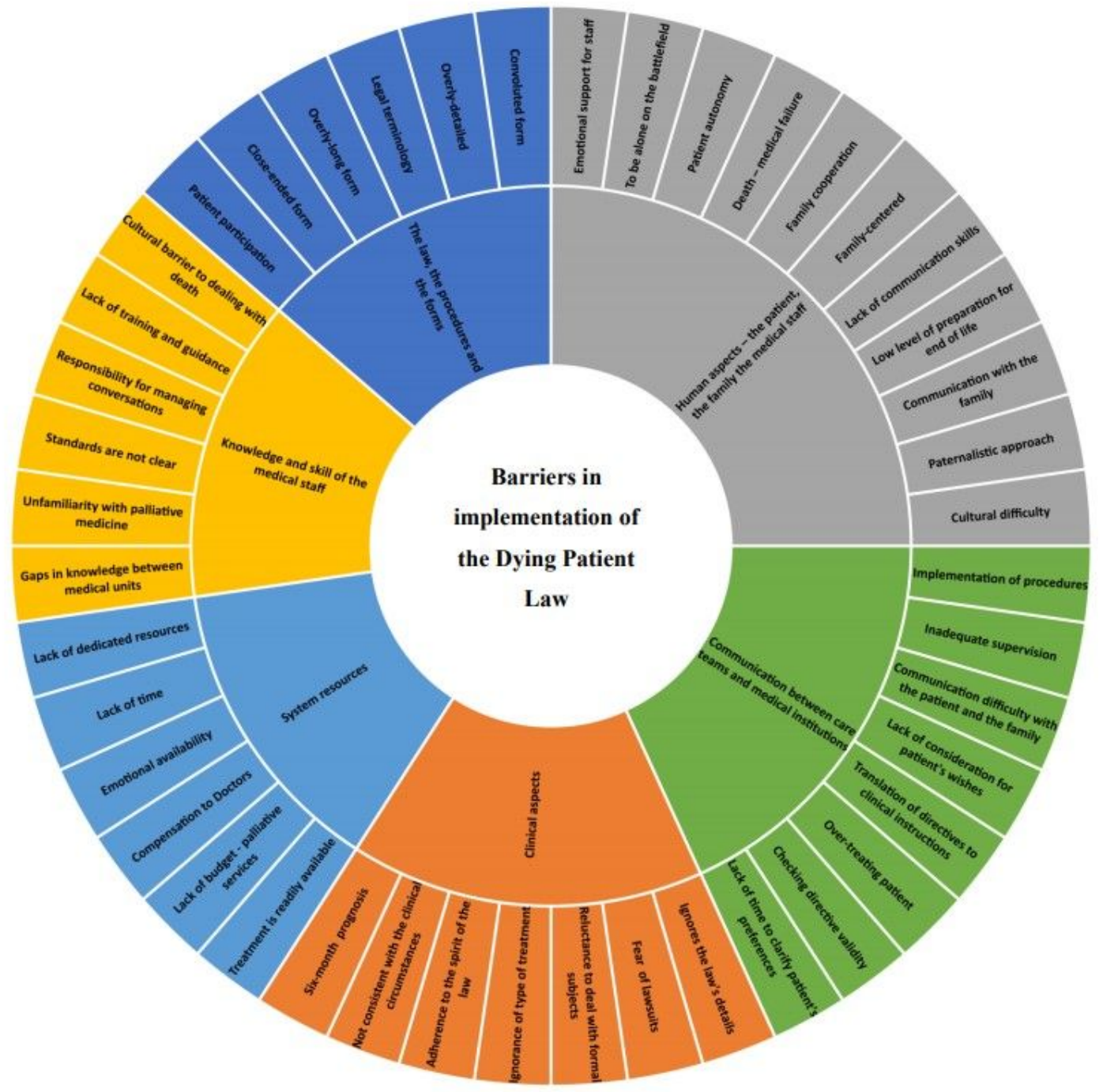

\section{Figure 1}

Barriers in the implementation of the Dying Patient Law 